\title{
Effect of Growth Regulators and Growth Media on Rooting of Semi Hardwood Cuttings of Rose Root Stocks
}

\author{
Sonam Dawa ${ }^{1 *}$, Z.A. Rather ${ }^{1}$, Phunstog Tundup ${ }^{2}$ and Tsewang Tamchos ${ }^{3}$ \\ ${ }^{1}$ Division of Floriculture and Landscape Architecture, S.K. University of Agricultural Sciences \\ and Technology of Kashmir, Shalimar, Srinagar, Jammu and Kashmir- 190025, India \\ ${ }^{2}$ Division of Soil Science, S.K. University of Agricultural Sciences and Technology of Kashmir, \\ Shalimar, Srinagar, Jammu and Kashmir- 190025, India \\ ${ }^{3}$ DIHAR DRDO, India \\ *Corresponding author
}

\section{A B S T R A C T}

The present investigation was carried out at Research Farm, Division of Floriculture and Landscape Architecture, SKUAST-Kashmir, Shalimar, Srinagar, J\&K (India) during the year 2010 to evaluate the effect of two growth regulators IBA and NAA @ 500, 1000, $1500 \mathrm{ppm}$ in comparison to control (without any growth regulator treatment) and growing

\section{Keywords}

Growing medium, IBA, NAA, Rootstocks, Rooting, Rose.

Article Info

Accepted: 12 March 2017 Available Online: 10 April 2017 medium combinations (sand 100\%, sand $85 \%$ + manure $15 \%$, sand $70 \%$ + manure $30 \%$, sand $70 \%+$ manure $15 \%+$ soil $15 \%$, sand $85 \%+$ soil $15 \%$ ) on the rooting of three rootstocks of rose (Rosa indica, Rosa banksiae and Rosa bourboniana). Main effect of growth regulators and genotype was significant on majority of rooting characteristics. IBA $(1000 \mathrm{ppm})$ recorded minimum days to root initiation (23.33), maximum rooting (72.22\%), root length $(6.42 \mathrm{~cm})$ and field survival $(82.38 \%)$. Among the genotype, Rosa indica performed better, recording maximum rooting $(75.24 \%)$, primary root number $(9.48)$, root length $(6.40 \mathrm{~cm})$, new leaf growth on cuttings $(59.05 \%)$ and field survival $(96.98 \%)$ followed by Rosa banksiae. Performance of Rosa bourboniana was poor recording lowest values for all these parameters. Interaction effects were significant. NAA produced superior results in Rosa indica while, IBA gave promising results in Rosa banksiae and Rosa bourboniana. Growing medium significantly improved various rooting characteristics of cuttings. Superior results were obtained with sand $70 \%+$ manure $30 \%$ which, recorded minimum days to root initiation (22.13), maximum rooting (83.33\%), primary root number $(15.52)$, root length $(8.88 \mathrm{~cm})$, new leaf growth $(51.11 \%)$ and field survival (85.46\%). Among the genotypes, Rosa indica consistently gave better results recording minimum days to root initiation (22.70), maximum rooting $(90.00 \%)$, primary root number $(21.21)$, root length $(10.10 \mathrm{~cm})$, new leaf growth $(47.33 \%)$ and field survival $(97.78 \%)$.

\section{Introduction}

Rose is the best known and most popular of all the garden flowers throughout the world. Rose occupies the second position among the top cut flowers in the world flower trade
(Sudhagar, 2013). The Netherland is the leading rose exporter followed by Columbia and Israel (Bose et al., 2002). India is emerging rose cut flower producing country 
and the crops is grown on an approximately $20 \%$ of the total area under ornamental plants in India (Sudhagar, 2013). Roses are conveniently propagated by cuttings, budding, grafting and layering. Among these, the use of stem cuttings is most easy and common method of growing roses. Propagation through cuttings is the simplest way to increase the desirable rose cultivars but success rate is limited in many types due to failure in root formation. Plant growth regulators have been used to promote rooting in many ornamental plants including roses (Pandey and Sinha, 1997).

The performance of varieties depends to a large extent on the availability of rootstock suitable for local soil and climatic conditions. Kaicker and Dhayani (1986) evaluated twelve indigenous and exotic rootstocks of rose and found Rosa indica var. odorata suitable for North Indian plains particularly for saline soils and Rosa bourboniana suitable for whole country. The commercial cultivation of rose in Jammu and Kashmir state depends upon the availability of planting material of good cut flower cultivars and their suitability to the local environment. Performance of the new cultivars can be increased to some extent if budded upon the locally available rootstocks. Thus multiplication of local rootstocks is very important for commercialization of rose in the state so that quality planting material budded on suitable rootstocks can be distributed among the growers for large scale cultivation. Accordingly present experiment was planned to multiply the local rootstocks of roses through stem cuttings using different auxins and growing media for increasing their rooting characteristics.

\section{Materials and Methods}

The present investigations were carried out at the Research Farm of Division of Floriculture and Landscape Architecture, SKUAST- (K), Shalimar Campus, Srinagar (J\&K) during the year 2010. Mature plants of three rose genotypes viz., Rosa indica, Rosa bourboniana and Rosa banksiae var. lutea, growing under open conditions for the last 5 years, were selected as stock plants for collecting semi-hardwood cutting material. First experiment was conducted to find out the effect of indole butyric acid (IBA) and naphthalene acetic acid (NAA) on various rooting parameters of rose. The stock solutions of growth regulators were prepared in ethanol and diluted to various concentrations (viz., 500, 1000 and 1500 ppm) using distilled water. The experiment was laid out in the underground cellars (propagation chambers) with a dimension of $2 \mathrm{~m} \times 1 \mathrm{~m} \times 0.5 \mathrm{~m}$. The cellars were covered with transparent polythene from top using wooden frames for providing support to sheets. Tin trays $(60 \mathrm{~cm} \times 40 \mathrm{~cm} \times 10 \mathrm{~cm})$ were filled with rooting medium (washed river sand) and drenched with $0.02 \%$ bavistin five days before planting cuttings into the medium. Sand filled trays were kept under semi-shade conditions for the first two days and shifted to underground cellars for planting of cuttings.

The semi-hard wood cuttings consisting of 4 nodes with leaves intact on each node were taken from the middle portion of the vigorously growing shoots during morning hours. Each cutting was prepared by giving a flat round cut at the basal portion just below the lower bud and another slanting cut $2.0 \mathrm{~cm}$ away from the top node. Lower leaves on the cuttings were removed to avoid their contact with the rooting medium. The cuttings were bundled into sets of 5cutting/treatment/replication. The basal portion of cuttings $(1.0 \mathrm{~cm})$ was dipped into the freshly prepared auxin solution as per treatment for 20 seconds. For control, cuttings were dipped in distilled water for same 
duration. Treated cuttings were immediately planted in sand filled trays with the help of a dibbler at a distance of $5.0 \mathrm{~cm}$ from cutting and $0.8 \mathrm{~cm}$ between rows. Light overhead watering was done to settle the cuttings without any risk of leaching off of the rooting chemical.

Second experiment was conducted to find out the effect of growing media combinations on the various rooting parameters of rose. Different combinations of growing media (sand, garden soil, well rotten farmyard manure) were made on volume basis using one liter plastic bucket for mixing required quantities of growing medium. Different medium components were then thoroughly mixed and filled in the plastic glasses up to brim. Few holes were made at the bottom of each glass to ensure free drainage. Medium filled plastic glasses were thoroughly watered with the $0.02 \%$ bavistin solution and kept under semi-shade for a few days. Semi hardwood cuttings treated with IBA (1000 ppm) were planted in these glasses and kept in underground cellars for rooting. The cellars were covered with transparent polythene from top using wooden frames for providing support to sheets.

The experiments were conducted in a completely randomized design with each treatment replicated three times. The data recorded after 31 days on different rooting parameters was subjected to analysis of variance using Minitab statistical package. Days to root initiation was recorded by taking out extra cuttings after 3 days interval starting from $5^{\text {th }}$ day onwards and field survival was recorded one month after transplanting the rooted cuttings in the field. Temperature in the cellars ranged between $18-22^{\circ} \mathrm{C}$ and humidity between $80-90 \%$ during the study period. To satisfy the model assumptions for analysis of variance, percentage data was subjected to angular transformation. Mean comparison was performed by using least significant difference (LSD) test.

\section{Results and Discussion}

Growth regulators and genotypes had a significant effect on various rooting characteristics of stem cuttings of rose (Table 1). Significant variation was observed in time taken to root initiation in cuttings. Minimum number of days (23.33) taken to root initiation was observed in cuttings treated with IBA @ 1000 ppm which was at par with IBA @ 500 ppm (23.67 days). However, maximum time (26.00 days) taken to root initiation was noticed in untreated cuttings in control. These results are in close conformity with the findings of Bharathy et al., (2004) in carnation. The decrease in time taken to root initiation may be attributed to the fact that application of exogenous growth regulators might have supplemented endogenous auxin levels and brought about certain anatomical and physiological changes in the cuttings leading to early root initiation. Rosa indica took minimum number of days (22.81days) to root initiation while Rosa bourboniana took maximum time (25.71 days). Difference in root initiation among genotypes might be due to different amounts of carbohydrates and phenolic compounds in cuttings, which get reduced at the time of root initiation and favour rooting in cuttings (Patil and Shirol, 1991). The interaction between growth regulator and genotype was found nonsignificant.

Highest rooting $(72.22 \%)$ and maximum root length $(6.42 \mathrm{~cm})$ was recorded with IBA 1000 ppm, while lowest of $55.56 \%$ and $4.26 \mathrm{~cm}$ in control. Maximum root number (8.59) was observed with NAA 1000 ppm. IBA was found more effective than NAA in improving rooting percentage and root length in cuttings. The increase in percentage of rooting as a result of IBA treatments may be due to the 
fact that IBA helps in mobilization of reserve food materials, elongation of meristematic cells and differentiation of cambial initials into root primordial (Younis and Riaz, 2005). Exogenous auxin treatment have been reported to increase the number of root primordia in the basal part of the cuttings, which led to increased rooting and root number (Rolston et al., 1996). Similar finding have been observed by Akhtar et al., (2002) in different species of rose, Bhuse et al., (2003) in Pelargonium graveolens and Pandey et al., (2011) in Gingko biloba following auxin treatments.

Among the genotypes tested, highest rooting (75.24\%), root number (9.48) and root length $(6.40 \mathrm{~cm})$ was recorded in Rosa indica. All these rooting parameters recorded lowest values in Rosa bourboniana. Differences in rooting characteristics among the rootstocks may be attributed to genetic compositions and carbohydrate content of cuttings. Cuttings of Rosa indica might have higher amount of internal stored carbohydrates and other root promoting factors as compared to other two species, which resulted better rooting characteristics. These results are in close conformity with the findings of Demetrios et al., (2004) in Arbutus unedo and Taxus baccata. The interaction between growth regulators and genotypes was significant with highest rooting $(93.33 \%)$ and primary root number (16.53) in Rosa indica with NAA 1000 ppm, while lowest in Rosa bourboniana under control.

Production of new leaves on the cuttings and their field survival was significantly influenced by growth regulators. Maximum number of cuttings $(43.33 \%)$ which developed new leaves was recorded with NAA @ 1000 ppm, which was at par $(42.22 \%)$ with IBA @ 1000 ppm and highest field survival (82.38\%) with IBA @1000 ppm. Both these parameters recorded minimum values under control. Development of new leaves in cuttings might be associated with the increased root number and length in treated cuttings, which helped them in better nutrient and moisture utilization from the growing medium and hence more growth in the form of new leaves and better survival. These findings are in conformity with the results of Hayashi and Kawano (2003) in Rosa cv. Tinek.

Number of cuttings with new leaves $(59.05 \%)$ and their field survival (96.98\%) was recorded maximum in Rosa indica and minimum of $20.95 \%$ and $43.38 \%$ in Rosa bourboniana. Superiority of Rosa indica with respect to development of new leaves and survival might be attributed to better utilization of nutrients from the growing medium by dent of its maximum root number and root length. Similar results were reported by Abbas et al., (2006) in Rosa damascena and Rosa centifolia, Bharathy et al., (2004) in carnation, Majeed et al., (2009) in Aesculus indica, Rahman et al., (2003) in guava and Hussain and Khan (2004) in Rosa bourboniana. Significant interaction resulted in the production of maximum cuttings with new leaves $(80.00 \%)$ in Rosa indica when treated with NAA $1000 \mathrm{ppm}$, while it was non-significant for survival.

Growth media and genotypes had a significant effect on various rooting characteristics (Table 2). Days taken to root initiation was observed minimum (22.13) in cuttings rooted in medium containing sand $70 \%+$ manure $30 \%$ and maximum $(27.00$ days) in medium containing sand $85 \%+$ soil $15 \%$. The decrease in time taken to root initiation might be due to the excellent drainage, good aeration and higher temperature in manure supplemented media. These results are in close conformity with the findings of Ochoa et al., (2003) in oleander cuttings and Dvin et al., (2011) in cuttings of MM111 apple. 
Table.1 Effect of growth regulators and genotype on various rooting characteristics of semi-hardwood cuttings of rose

\begin{tabular}{|c|c|c|c|c|c|c|c|c|c|c|c|c|c|c|c|c|c|c|c|c|c|c|c|c|}
\hline \multirow{2}{*}{$\begin{array}{l}\text { PGRs/ } \\
\text { Genotypes }\end{array}$} & \multicolumn{4}{|c|}{ Days take to root initiation } & \multicolumn{4}{|c|}{ Rooting (\%) } & \multicolumn{4}{|c|}{ Primary root number } & \multicolumn{4}{|c|}{ Root length $(\mathrm{cm})$} & \multicolumn{4}{|c|}{ Cutting with new leaves (\%) } & \multicolumn{4}{|c|}{ Field survival (\%) } \\
\hline & G1 & G2 & G3 & Mean & G1 & G2 & G3 & Mean & G1 & G2 & G3 & Mean & G1 & G2 & G3 & Mean & G1 & G2 & G3 & Mean & G1 & G2 & G3 & Mean \\
\hline Control & 28.00 & 26.00 & 24.00 & 26.00 & $\begin{array}{c}33.33 \\
(35.22)\end{array}$ & $\begin{array}{c}63.33 \\
(52.78)\end{array}$ & $\begin{array}{l}70.00 \\
(56.9)\end{array}$ & $\begin{array}{l}55.56 \\
(48.3)\end{array}$ & 2.23 & 4.6 & 4.8 & 3.88 & 3.03 & 4.2 & 5.53 & 4.26 & $\begin{array}{c}13.33 \\
(21.15)\end{array}$ & $\begin{array}{c}30.00 \\
(33.00)\end{array}$ & $\begin{array}{c}46.67 \\
(43.08)\end{array}$ & $\begin{array}{c}30.00 \\
(32.41)\end{array}$ & $\begin{array}{c}30.16 \\
(33.29)\end{array}$ & $\begin{array}{c}79.26 \\
(62.91)\end{array}$ & $\begin{array}{c}89.63 \\
(71.22)\end{array}$ & $\begin{array}{c}66.35 \\
(55.81)\end{array}$ \\
\hline IBA $500 \mathrm{ppm}$ & 25.00 & 24.00 & 22.00 & 23.67 & $\begin{array}{c}56.67 \\
(48.85)\end{array}$ & $\begin{array}{c}73.33 \\
(59.01)\end{array}$ & $\begin{array}{l}80.00 \\
(63.9)\end{array}$ & $\begin{array}{l}70.00 \\
(57.2)\end{array}$ & 3.2 & 8.2 & $\begin{array}{c}6.6 \\
7\end{array}$ & 6.02 & 3.27 & 6.2 & 6.1 & 5.19 & $\begin{array}{c}20.00 \\
(26.07)\end{array}$ & $\begin{array}{c}30.00 \\
(33.00)\end{array}$ & $\begin{array}{c}56.67 \\
(48.85)\end{array}$ & $\begin{array}{c}35.56 \\
(35.97)\end{array}$ & $\begin{array}{c}47.50 \\
(43.56)\end{array}$ & $\begin{array}{c}92.96 \\
(77.36)\end{array}$ & $\begin{array}{c}96.29 \\
(83.51)\end{array}$ & $\begin{array}{c}78.92 \\
(68.14)\end{array}$ \\
\hline IBA $1000 \mathrm{ppm}$ & 24.00 & 23.00 & 23.00 & 23.33 & $\begin{array}{c}63.33 \\
(52.78)\end{array}$ & $\begin{array}{c}83.33 \\
(66.15)\end{array}$ & $\begin{array}{l}70.00 \\
(56.9)\end{array}$ & $\begin{array}{l}72.22 \\
(58.6)\end{array}$ & 4.47 & $\begin{array}{c}9.1 \\
3\end{array}$ & $\begin{array}{c}7.3 \\
3\end{array}$ & 6.98 & 3.87 & 8.6 & 6.8 & 6.42 & $\begin{array}{c}33.33 \\
(35.22)\end{array}$ & $\begin{array}{c}40.00 \\
(39.23)\end{array}$ & $\begin{array}{c}53.33 \\
(47.01)\end{array}$ & $\begin{array}{c}42.22 \\
(40.49)\end{array}$ & $\begin{array}{c}54.17 \\
(47.41)\end{array}$ & $\begin{array}{c}96.29 \\
(83.51)\end{array}$ & $\begin{array}{c}96.67 \\
(83.85)\end{array}$ & $\begin{array}{c}82.38 \\
(71.59)\end{array}$ \\
\hline IBA $1500 \mathrm{ppm}$ & 24.33 & 25.00 & 24.00 & 24.44 & $\begin{array}{c}50.00 \\
(45.00)\end{array}$ & $\begin{array}{c}66.67 \\
(54.78)\end{array}$ & $\begin{array}{l}56.67 \\
(48.8)\end{array}$ & $\begin{array}{l}57.79 \\
(49.5)\end{array}$ & 3.03 & 7.3 & 6 & 5.44 & 3.77 & 7.8 & 5.2 & 5.59 & $\begin{array}{c}26.67 \\
(30.99)\end{array}$ & $\begin{array}{c}26.67 \\
(30.99)\end{array}$ & $\begin{array}{c}46.67 \\
(43.01)\end{array}$ & $\begin{array}{c}33.33 \\
(35.02)\end{array}$ & $\begin{array}{c}47.50 \\
(43.56)\end{array}$ & $\begin{array}{c}89.26 \\
(74.48)\end{array}$ & $\begin{array}{c}96.29 \\
(83.51)\end{array}$ & $\begin{array}{c}77.68 \\
(67.18)\end{array}$ \\
\hline NAA $500 \mathrm{ppm}$ & 27.00 & 25.00 & 21.00 & 24.33 & $\begin{array}{c}50.00 \\
(45.00)\end{array}$ & $\begin{array}{c}56.67 \\
(48.85)\end{array}$ & $\begin{array}{l}83.33 \\
(66.1)\end{array}$ & $\begin{array}{l}63.33 \\
(53.3)\end{array}$ & 2.4 & 7.6 & $\begin{array}{c}10 . \\
8\end{array}$ & 6.93 & 3.1 & 5 & 7.1 & 5.07 & $\begin{array}{c}16.67 \\
(23.85)\end{array}$ & $\begin{array}{c}26.67 \\
(30.99)\end{array}$ & $\begin{array}{c}66.67 \\
(54.99)\end{array}$ & $\begin{array}{c}36.67 \\
(36.67)\end{array}$ & $\begin{array}{c}40.54 \\
(39.42)\end{array}$ & $\begin{array}{c}86.67 \\
(72.29)\end{array}$ & $\begin{array}{l}100.00 \\
(90.00)\end{array}$ & $\begin{array}{c}75.77 \\
(67.24)\end{array}$ \\
\hline $\begin{array}{l}\text { NAA } 1000 \\
\text { ppm }\end{array}$ & 25.00 & 24.00 & 23.00 & 24.00 & $\begin{array}{c}43.33 \\
(41.16)\end{array}$ & $\begin{array}{c}70.00 \\
(56.99)\end{array}$ & $\begin{array}{l}93.33 \\
(77.7)\end{array}$ & $\begin{array}{l}68.88 \\
(58.6)\end{array}$ & 3.03 & 6.2 & $\begin{array}{l}16 . \\
53\end{array}$ & 8.59 & 3.03 & 5.6 & 7.67 & 5.43 & $\begin{array}{c}20.00 \\
(26.07)\end{array}$ & $\begin{array}{c}30.00 \\
(33.00)\end{array}$ & $\begin{array}{c}80.00 \\
(63.93)\end{array}$ & $\begin{array}{c}43.33 \\
(41.00)\end{array}$ & $\begin{array}{c}43.33 \\
(41.15)\end{array}$ & $\begin{array}{c}90.47 \\
(79.23)\end{array}$ & $\begin{array}{l}100.00 \\
(90.00)\end{array}$ & $\begin{array}{c}77.94 \\
(70.13)\end{array}$ \\
\hline $\begin{array}{l}\text { NAA } 1500 \\
\text { ppm }\end{array}$ & 26.67 & 24.00 & 22.67 & 24.44 & $\begin{array}{c}43.33 \\
(41.16)\end{array}$ & $\begin{array}{c}50.00 \\
(45.00)\end{array}$ & $\begin{array}{l}73.33 \\
(59.7)\end{array}$ & $\begin{array}{l}55.57 \\
(48.6)\end{array}$ & 2.83 & 5.4 & $\begin{array}{c}14 . \\
2\end{array}$ & 7.48 & 2.97 & 4.9 & 6.4 & 4.76 & $\begin{array}{c}16.67 \\
(23.85)\end{array}$ & $\begin{array}{c}26.68 \\
(30.99)\end{array}$ & $\begin{array}{c}63.33 \\
(52.78)\end{array}$ & $\begin{array}{c}35.56 \\
(35.88)\end{array}$ & $\begin{array}{c}40.47 \\
(39.40)\end{array}$ & $\begin{array}{c}86.29 \\
(68.51)\end{array}$ & $\begin{array}{l}100.00 \\
(90.00)\end{array}$ & $\begin{array}{c}75.59 \\
(65.99)\end{array}$ \\
\hline Mean & 25.71 & 24.43 & 22.81 & & $\begin{array}{c}48.57 \\
(44.16)\end{array}$ & $\begin{array}{c}66.19 \\
(54.79)\end{array}$ & $\begin{array}{c}75.24 \\
(61.48)\end{array}$ & & 3.03 & $\begin{array}{c}6.9 \\
2\end{array}$ & $\begin{array}{c}9.4 \\
8\end{array}$ & & 3.29 & $\begin{array}{c}6.0 \\
4\end{array}$ & 6.4 & & $\begin{array}{c}20.95 \\
(26.74)\end{array}$ & $\begin{array}{c}30.00 \\
(33.03)\end{array}$ & $\begin{array}{c}59.05 \\
(50.53)\end{array}$ & & $\begin{array}{c}43.38 \\
(41.12)\end{array}$ & $\begin{array}{c}88.74 \\
(74.04)\end{array}$ & $\begin{array}{c}96.98 \\
(84.58)\end{array}$ & \\
\hline \multicolumn{5}{|c|}{\begin{tabular}{|lc} 
C.D. $(\mathrm{p} \leq 0.05)$ & \\
Growth regulator & 1.408 \\
Genotype & 0.922 \\
Interaction & NS
\end{tabular}} & \multicolumn{4}{|c|}{$\begin{array}{l}5.081 \\
3.326 \\
8.799\end{array}$} & \multicolumn{4}{|c|}{$\begin{array}{l}0.559 \\
0.366 \\
0.969\end{array}$} & \multicolumn{4}{|c|}{$\begin{array}{l}0.568 \\
0.371 \\
0.981\end{array}$} & \multicolumn{4}{|c|}{$\begin{array}{l}5.089 \\
3.332 \\
8.814\end{array}$} & \multicolumn{4}{|c|}{$\begin{array}{c}8.321 \\
5.448 \\
\text { NS }\end{array}$} \\
\hline
\end{tabular}


Int.J.Curr.Microbiol.App.Sci (2017) 6(4): 1042-1051

Table.2 Effect of growing media and genotype on various rooting characteristics of semi-hardwood cuttings of rose

\begin{tabular}{|c|c|c|c|c|c|c|c|c|c|c|c|c|c|c|c|c|c|c|c|c|c|c|c|c|}
\hline \multirow{2}{*}{$\begin{array}{c}\text { Media / } \\
\text { Genotypes }\end{array}$} & \multicolumn{4}{|c|}{ Days to root initiation } & \multicolumn{4}{|c|}{ Rooting (\%) } & \multicolumn{4}{|c|}{ Primary root number } & \multicolumn{4}{|c|}{ Root length (cm) } & \multicolumn{4}{|c|}{$\begin{array}{c}\text { Cuttings with new } \\
\text { leaves }(\%)\end{array}$} & \multicolumn{4}{|c|}{ Field survival (\%) } \\
\hline & G1 & G2 & G3 & Mean & G1 & G2 & G3 & Mean & G1 & G2 & G3 & Mean & G1 & G2 & G3 & Mean & G1 & G2 & G3 & Mean & G1 & G2 & G3 & Mean \\
\hline $\begin{array}{l}\text { Sand } \\
(100 \%)\end{array}$ & 25.20 & 24.60 & 22.00 & 23.93 & $\begin{array}{c}50.00 \\
(45.00)\end{array}$ & $\begin{array}{c}70.00 \\
(56.99)\end{array}$ & $\begin{array}{c}86.67 \\
(72.29)\end{array}$ & $\begin{array}{c}68.89 \\
(58.09)\end{array}$ & 6.33 & 4.23 & 18.43 & 9.67 & 4.60 & 5.87 & 9.57 & 6.68 & 33.33 & 40.00 & 43.33 & 38.89 & $\left|\begin{array}{c}43.91 \\
(41.45)\end{array}\right|$ & $\mid \begin{array}{c}85.92 \\
68.16)\end{array}$ & $\begin{array}{c}96.29 \\
(83.51)\end{array}$ & $\begin{array}{c}75.37 \\
(64.37)\end{array}$ \\
\hline $\begin{array}{c}\text { Sand } 85 \%+ \\
\text { Manure } \\
15 \%\end{array}$ & 24.10 & 24.80 & 21.20 & 23.37 & $\begin{array}{c}63.33 \\
(52.78)\end{array}$ & $\begin{array}{c}80.00 \\
(63.93)\end{array}$ & $\begin{array}{c}96.67 \\
(83.86)\end{array}$ & \begin{tabular}{|c|}
80.00 \\
$(66.85)$
\end{tabular} & 11.93 & 6.77 & 24.07 & 14.26 & 7.13 & 6.87 & 11.10 & 8.37 & 40.00 & 43.33 & 56.67 & 46.67 & $\begin{array}{c}60.47 \\
(51.15)\end{array} \mid$ & $\begin{array}{c}90.74 \\
(75.48)\end{array}$ & $\begin{array}{l}100.00 \\
(90.00)\end{array}$ & $\begin{array}{c}83.74 \\
(72.21)\end{array}$ \\
\hline $\begin{array}{c}\text { Sand } 70 \%+ \\
\text { Manure } \\
30 \%\end{array}$ & 23.40 & 23.00 & 20.00 & 22.13 & $\begin{array}{c}70.00 \\
(56.99)\end{array}$ & $\begin{array}{l}83.33 \\
(66.15)\end{array}$ & $\begin{array}{c}96.67 \\
(83.86)\end{array}$ & $\begin{array}{c}83.33 \\
(68.99)\end{array}$ & 12.57 & 8.47 & 25.53 & 15.52 & 8.23 & 7.13 & 11.27 & 8.88 & 43.33 & 46.67 & 63.33 & 51.11 & $\left|\begin{array}{c}63.05 \\
(52.58)\end{array}\right|$ & $\mid \begin{array}{c}93.33 \\
(77.71)\end{array}$ & $\begin{array}{l}100.00 \\
(90.00)\end{array}$ & $\begin{array}{c}85.46 \\
(73.43)\end{array}$ \\
\hline $\begin{array}{c}\text { Sand } 70 \%+ \\
\text { Manure } \\
15 \%+ \\
\text { Soil } 15 \%\end{array}$ & 24.40 & 25.80 & 24.10 & 24.77 & $\begin{array}{c}56.67 \\
(48.85)\end{array}$ & $\begin{array}{c}63.33 \\
(52.86)\end{array}$ & $\begin{array}{c}90.00 \\
(75.00)\end{array}$ & \begin{tabular}{|c|}
70.00 \\
$(58.90)$
\end{tabular} & 5.23 & 6.37 & 21.37 & 10.99 & 4.13 & 6.07 & 10.03 & 6.74 & 30.00 & 36.67 & 40.00 & 35.56 & $\left|\begin{array}{c}47.62 \\
(43.63)\end{array}\right|$ & $\mid \begin{array}{c}89.63 \\
(74.65)\end{array}$ & $\begin{array}{c}96.29 \\
(83.51)\end{array}$ & $\begin{array}{c}77.85 \\
(67.26)\end{array}$ \\
\hline $\begin{array}{c}\text { Sand } 85 \%+ \\
\text { Soil } \\
15 \%\end{array}$ & 28.00 & 26.80 & 26.20 & 27.00 & $\begin{array}{l}36.67 \\
(27.23)\end{array}$ & $\begin{array}{c}46.67 \\
(43.08)\end{array}$ & $\begin{array}{r}80.00 \\
(63.93)\end{array}$ & $\begin{array}{c}54.44 \\
(48.08)\end{array}$ & 4.13 & 3.63 & 16.63 & 8.13 & 3.37 & 4.13 & 8.53 & 5.34 & 26.67 & 30.00 & 33.33 & 30.00 & $\begin{array}{c}40.65 \\
(39.60)\end{array}$ & $\mid \begin{array}{c}85.92 \\
(68.16)\end{array}$ & $\begin{array}{c}96.29 \\
(83.51)\end{array}$ & $\begin{array}{l}74.29 \\
(63.76)\end{array}$ \\
\hline Mean & 25.02 & 25.00 & 22.70 & & $\begin{array}{c}55.33 \\
(48.17)\end{array}$ & $\begin{array}{c}68.67 \\
(56.60)\end{array}$ & $\begin{array}{c}90.00 \\
(75.79)\end{array}$ & & 8.04 & 5.89 & 21.21 & & 5.49 & 6.01 & 10.10 & & 34.67 & 39.33 & 47.33 & & $\mid \begin{array}{c}51.14 \\
(45.68)\end{array}$ & $\begin{array}{c}89.12 \\
(72.83)\end{array}$ & $\begin{array}{c}97.78 \\
86.10)\end{array}$ & \\
\hline $\begin{array}{l}\text { C.D. }(\mathrm{p} \leq \\
0.05) \\
\text { Growing } \\
\text { medium } \\
\text { Genotype } \\
\text { Interaction }\end{array}$ & & & & $\begin{array}{c}1.212 \\
0.939 \\
\text { NS }\end{array}$ & & & & $\begin{array}{c}7.932 \\
6.144 \\
\text { NS }\end{array}$ & & & & $\begin{array}{l}0.909 \\
0.703 \\
1.573\end{array}$ & & & & $\begin{array}{l}0.524 \\
0.406 \\
0.907\end{array}$ & & & & $\begin{array}{c}9.733 \\
7.539 \\
\text { NS }\end{array}$ & & & & $\begin{array}{c}7.762 \\
6.013 \\
\text { NS }\end{array}$ \\
\hline
\end{tabular}

$\mathrm{G} 1=$ Ros a bourboniana, $\mathrm{G} 2=$ Rosa banksiae $\mathrm{G} 3=$ Rosa indica 
Plate.1 Effect of growing medium on rooting in rose genotypes

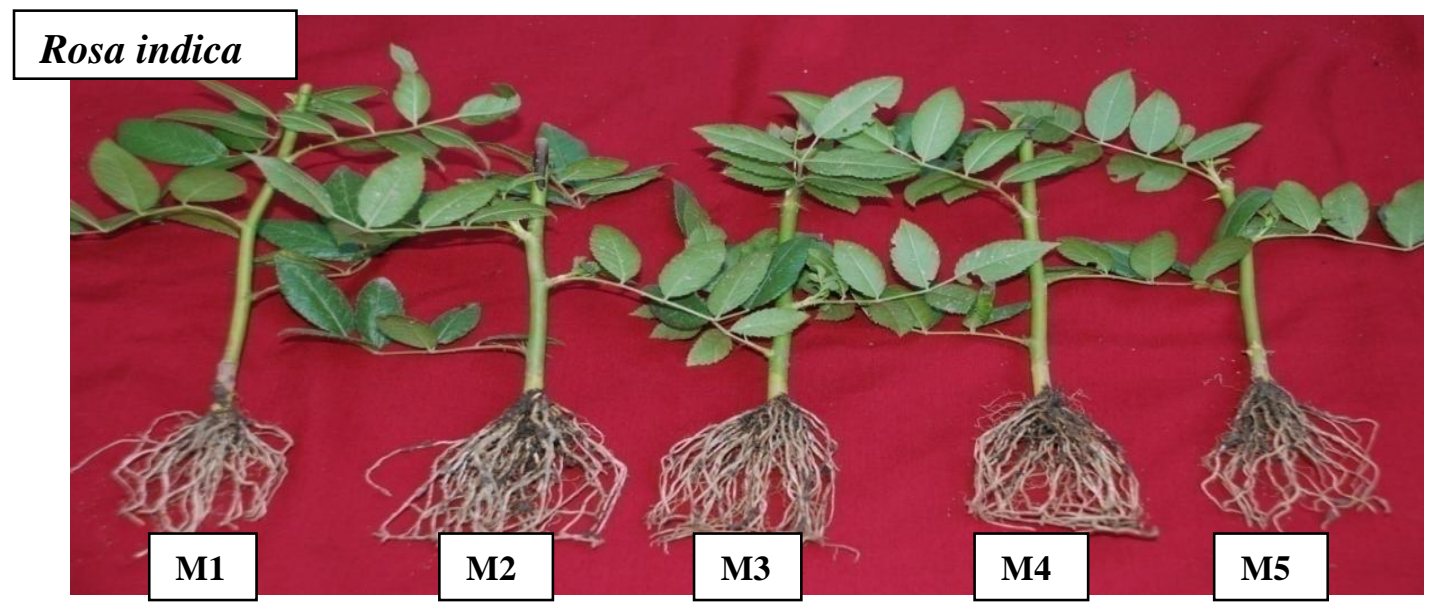

\section{Rosa banksiae}
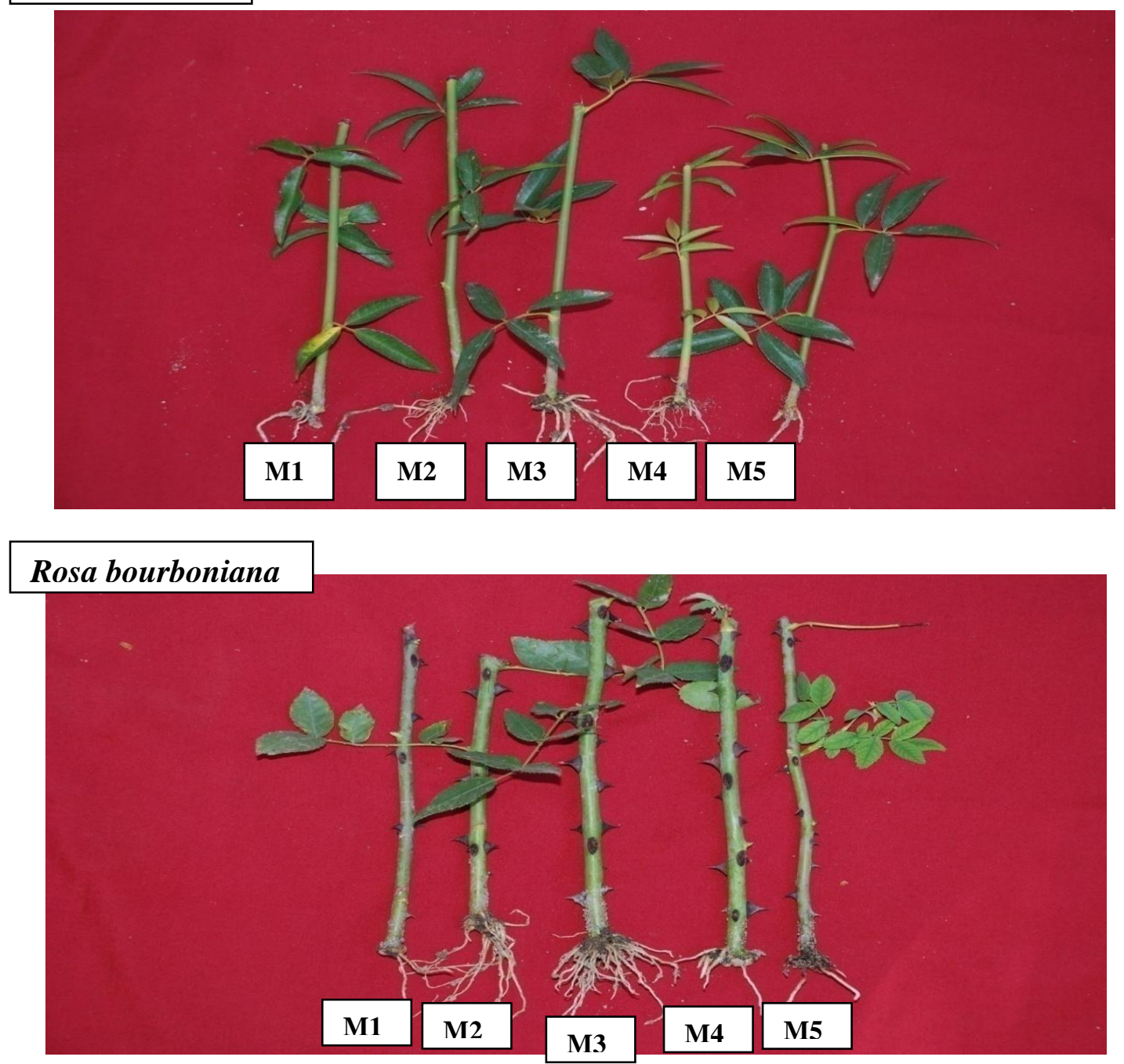

$[\mathrm{M} 1=$ Sand $100 \% ; \mathrm{M} 2=$ Sand $85 \%+$ Manure 15\%; M3=Sand 70\% + Manure 30\%; M4=Sand 70\% + Manure 15\% + Sand 15\%; M5= Sand 85\% + Soil 15\%]. 
Among the genotypes, minimum number of days (22.70) to root initiation was recorded in Rosa indica and maximum (25.02 days) in Rosa bourboniana which was at par with Rosa banksiae (25.00 days). Similar findings were reported by Abbas et al., (2006) in Rosa damascena and Rosa centifolia. The interaction between growing medium and genotype was found non-significant.

There was a significant effect of growing media on the rooting of cuttings. Highest rooting $(83.33 \%)$, primary root number (15.52) and root length (8.88 cc) was observed in media containing sand $70 \%+$ manure $30 \%$ and lowest rooting $(54.44 \%)$, primary root number $(8.13)$ and root length $(5.34 \mathrm{~cm})$ in media supplemented with sand $85 \%+$ soil 15\% (Plate 1). Improved rooting characteristics in manure and sand based medium might be due to good drainage, aeration, better nutrition and water holding capacity of media. These results lend support from the results of Ercisli et al., (2002) in hardwood cuttings of kiwifruit. These results are supported with the results of Ochoa et al., (2003) in oleander cuttings and Ulemale et al., (2003) in rose cuttings. These results are in close agreement with the findings of Ochoa et al., (2003) in oleander cuttings and Khan et al., (2007) in rose cuttings.

Among the genotypes, maximum rooting $(90.00 \%)$, primary root number $(21.21)$ and root length $(10.10 \mathrm{~cm})$ was observed in Rosa indica. Minimum rooting $(55.33 \%)$ and root length $(5.49 \mathrm{~cm})$ was observed in Rosa bourboniana. Primary root number was observed minimum (5.89) in Rosa banksiae. Variation in rooting characteristics of different genotypes may be attributed to their genetic characteristics or variation in auxin and carbohydrate content in cuttings, due to which some plants root profusely while others fail to root. Similar results were reported by Polat and Caliskan (2009) in pomegranate;
Abbas et al., (2006), Hussain and Khan (2004) and Akhtar et al., (2002) in rose. Significant differences in rooting percentage among genotypes were also reported by Yazici et al., (2009) in cherry laurel and Saed (2010) in pomegranate. The interaction between growing medium and genotype was found non-significant for all these parameters.

Medium had a significant effect on the growth of new leaves on the cuttings (Table 2). Maximum number of cuttings (51.11\%) which developed new leaves was recorded in media (sand 70\%+ manure 30\%) and minimum of $30 \%$ in (sand $85 \%+$ soil 15\%). The increase in new leaf emergence might be due to high porosity and water holding capacity, good nutrient content and aeration of media containing sand and manure. These results are in close conformity with findings of Mamba and Wahome (2010) in geranium, where inclusion of compost with sand and soil increased the number of new leaves on cuttings. Among the genotypes, the number of cuttings with new leaves was maximum $(47.33 \%)$ in Rosa indica and minimum $(34.67 \%)$ in Rosa bourboniana. Similar findings were also recorded by Shah et al., (2006) in Ficus binnendijkii and Akhtar et al., (2002) in stem cuttings of Rosa centifolia and Rosa damascena. The interaction between growing medium and genotype was found non-significant.

Survival of rooted cuttings in the field was significantly increased when cuttings were rooted in manure supplemented medium. Maximum survival $(85.46 \%)$ was recorded in cuttings grown in manure supplemented media (sand 70\%+ manure 30\%) and minimum $(74.29 \%)$ in cuttings grown in (sand $85 \%+$ soil $15 \%$ ). The increase in field survival percentage might be due to the profuse root production of cuttings in manure rich media having more nutrients, good aeration and water holding capacity. Similar findings were 
also reported by Khan et al., (2007) in rose. Among the genotypes, maximum survival (97.78\%) was recorded in Rosa indica and minimum (51.14\%) in Rosa bourboniana. Similar findings were also reported by Gupta and Kher (1991) in Boungainvillea. cv. Garnet Glory. The interaction between growing medium and genotype was found non-significant.

\section{References}

Abbas, H., Jaskani, M. J., Hussain, Z. and Asif, M. 2006. Response of rose cuttings against root promoting hormones during spring and autumn. Int. J. Biol. Biotechnol., 3(1): 201-204.

Akhtar, M.S., Khan, M.A., Atif-Riaz. and Adnan-Younis. 2002. Response of different rose species to different root promoting hormones. Pak. J. Agri. Sci., 39(4): 297-299.

Bharathy, P.V., Sonawane, P.C. and Sasnu, A. 2004. Effect of plant growth regulators, type of cutting and season on rooting of carnation (Dianthus caryophyllus L.) cuttings. Indian J. Horticulture, 61(4): 338-341.

Bhuse, V.H., Lad, B.L., Patil, D.K. and Karade, V.M. 2003. Effect of time of planting, type of cutting and plant growth regulators on rooting in Pelargonium graveolens L. Herit. Indian J. Agri. Res., 37(1): 29-33.

Bose, T.K., Yadav, L., Pal, P., Das, P. and Parthasarathy, V.A. 2002. Commercial Flowers. Naya Prakash 2, Kailash Bose Street, Calcutta 1: 10-11.

Demetrios, M.J., Syros, T.D., Yupsaris, T. and Economou, A.S. 2004. Peroxidases during adventitious rooting in cuttings of Arbutus unedo and Taxus baccata as affected by plant genotype and growth regulator treatment. Plant Growth Regulation, 44: 257-266.

Dvin, R.S., Moghadam, G.E. and Kiani, M.
2011. Rooting response of hardwood cuttings of MM111 apple clonal rootstock to indole-butyric acid and rooting media. Asian J. Appl. Sci., 4(4): 453-458.

Ercisli, S., Anapali, O., Esitken, A. and Sahin, U. 2002. The effects of IBA, rooting media and cutting collection time on rooting of kiwifruit. Gartenbauwissenschaft, 67(1): 34:38.

Gupta, V.N. and Kher, M.A. 1991. A note on the influence of auxins in regeneration of roots in the tip cuttings of Bougainvillea sp. var. "Garnet Glory" under intermittent mist. Haryana $J$. Horticultural Sci., 20(1-2): 85-87.

Hayashi, M. and Kawano, K. 2003. Effect of $\mathrm{CO}_{2}$ enrichment on rooting and growth of rose cuttings. J. Society of High Technol. Agri., 15(4): 217-203.

Hussain, H. and Khan, M.A. 2004. Effect of growth regulators on stem cuttings of Rosa bourbonaina and Rosa gruss-anteplitz. Int. J. Agri. Biol., 6(5): 931-932.

Kaicker, U.S. and Dhayani, D. 1986. Performance of some indigenous and new exotic rose rootstocks in Delhi. Indian Rose Annual, 5: 145-154.

Khan, R.U., Khan, M.A., Abdur-Rashid and Farooq, M.A. 2007. Effect of exogenous indole-3-acetic acid and naphthalen e acetic acid on regeneration of damask rose cuttings in three growing media. Pak. J. Biol. Sci., 10(20): 3626- 3631.

Majeed, M., Khan, M.A. and Mughal, A.H. 2009. Vegetative propagation of Aesculus indica through stem cuttings treated with plant growth regulators. $J$. Forestry Res., 20(2): 171-173.

Mamba, B. and Wahome, P.K. 2010. Propagation of Geranium (Pelargonium hortorum) using different rooting medium components. AmericanEurasian J. Agri. Environ. Sci., 7(5): 497-500. 
Ochoa, J., Banon, S., Fernandez, J.A., Franco, J.A. and Gonzalez, A. 2003. Influence of cutting position and rooting media on rhizogenesis of oleander cuttings. Acta Horticulturae, 608: 101-106.

Pandey, A., Tamta, S. and Dinesh G. 2011. Role of auxin on adventitious root formation and subsequent growth of cutting raised plantlets of Ginkgo biloba L. Int. J. Biodiversity and Conservation, 3(4):142- 146.

Pandey, S.N. and Sinha, B.K. 1997. Plant Physiology. Vikas Publishing House, New Delhi, India.

Patil, A.A. and Shirol, A.M. 1991. Studies on rooting of oleander cuttings. South Indian Horticulture, 39: 48-53.

Polat, A.A. and Caliskan, O. 2009. Effect of indolebutyric acid (IBA) on rooting of cutting in various pomegranate genotypes. Acta Horticulturae, 818: 187-191.

Rahman, N., Tehsinullah., Nabi, G. and Jan, T. 2003. Effect of different growth regulators and types of cuttings on rooting of guava (Psidium guajaya L.). Sci. Vision, 9(1-2): 1-5.

Rolston, S.H., Carlos, A.F.B. and Carlos, A.P.M. 1996. Adventitious root formation and development in cuttings of Mussaenda erythrophylla L.
HortSci., 31: 1023-1025.

Saed, J.O. 2010. Rooting response of five pomegrante varieties to indole butryic acid concentration and cuttings age. Pak. J. Biol. Sci., 13: 51-58.

Shah, M., Khattak, A.M. and Amin, N. 2006. Effect of different growing media on the rooting of Ficus Binnedijkii 'Amstel Queen’ cuttings. J. Agri. Biol. Sci., 2: 15-17.

Sudhagar, S. 2013. Production and marketing of cut flower (Rose and Gerbera) in Hosur Taluk. Int. J. Business and Management Invention, 2(5): 15-25.

Ulemale, P.N., Chauhan, P.S., Rathod, T.H., Lawale, S.K. and Mahariya, A.D. 2003. Effect of growth regulators on propagation of roses by polybag method. Annals of Plant Physiol., 17(2): 137-139.

Yazici, K., Dal, B., Gozlekci, S., Kaynak, L. and Ersoy, N. 2009. Effects of cutting type and duration time on rooting of three cherry laurel (Prunus laurocerasus L.) genotypes. Acta Horticulturae, 818: 199-203.

Younis, A. and Riaz, A. 2005. Effect of various hormones and different rootstocks on rose propagation. Caderno de Pesquisa Serie Biologia, 17(1): 111-118.

\section{How to cite this article:}

Sonam Dawa, Z.A. Rather, Phunstog Tundup and Tsewang Tamchos. 2017. Effect of Growth Regulators and Growth Media on Rooting of Semi Hardwood Cuttings of Rose Root Stocks. Int.J.Curr.Microbiol.App.Sci. 6(4): 1042-1051. doi: https://doi.org/10.20546/ijcmas.2017.604.129 